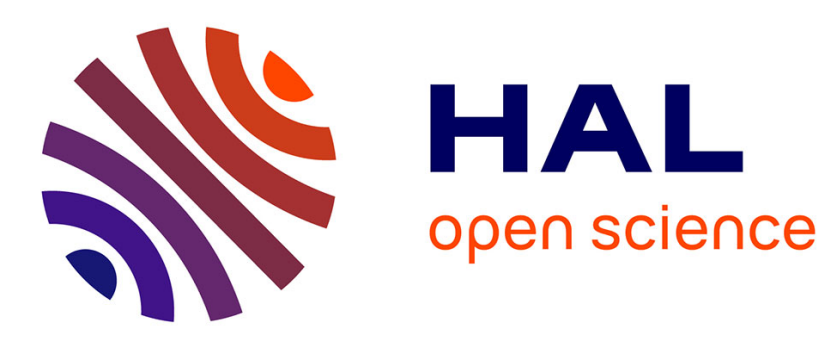

\title{
Biochemical characterization of a thermostable DNA ligase from the hyperthermophilic euryarchaeon Thermococcus barophilus Ch5
}

Haoqiang Shi, Yanchao Huang, Qi Gan, Mianwen Rui, Hongxun Chen, Chuandeng Tu, Zhihui Yang, Likui Zhang, P. Oger

\section{To cite this version:}

Haoqiang Shi, Yanchao Huang, Qi Gan, Mianwen Rui, Hongxun Chen, et al.. Biochemical characterization of a thermostable DNA ligase from the hyperthermophilic euryarchaeon Thermococcus barophilus Ch5. Applied Microbiology and Biotechnology, 2019, 10.1007/s00253-019-09736-9 . hal02091415

\section{HAL Id: hal-02091415 \\ https://hal.science/hal-02091415}

Submitted on 17 Jun 2020

HAL is a multi-disciplinary open access archive for the deposit and dissemination of scientific research documents, whether they are published or not. The documents may come from teaching and research institutions in France or abroad, or from public or private research centers.
L'archive ouverte pluridisciplinaire HAL, est destinée au dépôt et à la diffusion de documents scientifiques de niveau recherche, publiés ou non, émanant des établissements d'enseignement et de recherche français ou étrangers, des laboratoires publics ou privés. 


\title{
Biochemical characterization of a thermostable DNA ligase from the hyperthermophilic euryarchaeon Thermococcus barophilus Ch5
}

\author{
Haoqiang Shi ${ }^{\mathrm{a} *}$, Yanchao Huang ${ }^{\mathrm{a} *}$, Qi Gan ${ }^{\mathrm{a}}$, Mianwen Rui ${ }^{\mathrm{a}}$, Hongxun Chen ${ }^{\mathrm{a}}$, \\ Chuandeng Tu ${ }^{\mathrm{a}}$, Zhihui Yang ${ }^{\mathrm{b} \#}$, Philippe Oger ${ }^{\mathrm{c} \#}$ and Likui Zhang ${ }^{\mathrm{a} \#}$
}

${ }^{\mathrm{a}}$ Marine Science \& Technology Institute

Department of Environmental Science and Engineering, Yangzhou University, China

${ }^{\mathrm{b}}$ College of Plant Protection, Agricultural University of Hebei, Baoding City, Hebei Province 071001, China

${ }^{c}$ Université de Lyon, INSA de Lyon, CNRS UMR 5240, Lyon, France

* These authors contributed equally to this work.

Corresponding author: Dr. Likui Zhang

E-mail address:1kzhang@yzu.edu.cn

Tel: +86-514-89795882

Fax: $+86-514-87357891$

Corresponding author: Prof. Zhihui Yang

E-mail address: bdyzh@hebau.edu.cn

Corresponding author: Prof. Philippe Oger

E-mail address: philippe.oger@insa-lyon.fr 


\begin{abstract}
DNA ligases are essential enzymes for DNA replication, repair, and recombination processes by catalyzing a nick-joining reaction in double-stranded DNA. The genome of the hyperthermophilic euryarchaeon Thermococcus barophilus Ch5 encodes a putative ATP-dependent DNA ligase (Tba ligase). Herein, we characterized the biochemical properties of the recombinant Tba ligase. The enzyme displays an optimal nick-joining activity at $65 \sim 70^{\circ} \mathrm{C}$, and retains its DNA ligation activity even after heated at $100^{\circ} \mathrm{C}$ for 2 hours, suggesting the enzyme is a thermostable DNA ligase. The enzyme joins DNA over a wide $\mathrm{pH}$ spectrum ranging from 5.0-10.0, and its optimal $\mathrm{pH}$ is 6.0-9.0. Tba ligase activity is dependent on a divalent metal ion: $\mathrm{Mn}^{2+}, \mathrm{Mg}^{2+}$ or $\mathrm{Ca}^{2+}$ is an optimal ion for the enzyme activity. The enzyme activity is inhibited by $\mathrm{NaCl}$ with high concentrations. Remarkably, Tba ligase activity is independent on an additional nucleotide cofactor. However, ATP is required for Tba ligase activity when lowering the enzyme concentration. Mass spectrometric result shows that the residue K250 of Tba ligase is AMPylation, suggesting that the enzyme is bound to AMP. The substitution of K250 of Tba ligase with Ala abolishes the enzyme activity. These observations suggest that the enzyme is an ATP-dependent DNA ligase. In addition, the mismatches at the first position $3^{\prime}$ to the nick suppress Tba ligase activity more than those at the first position $5^{\prime}$ to the nick. The enzyme also discriminates more effectively mismatches at $3^{\prime}$ to the nick than those at $5^{\prime}$ to the nick in ligation cycling reaction, suggesting that the enzyme might have potential application in single nucleotide polymorphism.
\end{abstract}

Keywords: DNA ligase; Thermococcus barophilus; Thermostability; nucleotide cofactor; ligation cycling reaction 


\section{Introduction}

DNA ligases catalyze a sealing reaction of 5'-phosphate and 3'-hydroxyl termini at a single-stranded break in double-stranded DNA or at two fragments containing either complementary single-stranded or blunt ends (Lehman 1974). These enzymes play crucial roles in DNA replication, recombination and repair systems, and are thus indispensable in all organisms (Lindahl and Barnes 1992). In vitro, DNA ligases have also been widely utilized in many aspects of molecular biology and biotechnology (Chambers and Patrick 2015; Tanabe et al. 2015), thus allowing them to become a critical tool for modern biotechnology.

All DNA ligases catalyze the formation of a phosphodiester bond between DNA strands and are divided into two groups depending on their cofactors, ATP-dependent and $\mathrm{NAD}^{+}$-dependent (Tomkinson et al. 2006). ATP-dependent DNA ligases are ubiquitous in bacteria, bacteriophages, archaea, eukarya as well as eukaryotic viruses (Shuman 2009; Wilkinson et al. 2001; Ellenberger and Tomkinson 2008), whereas $\mathrm{NAD}^{+}$-dependent ligases are found only in bacteria (Doherty and Suh 2000). In the first step, the DNA ligase attacks the $\alpha$-phosphorus of ATP to release pyrophosphate (Doherty and Suh 2000). In the second step, it forms a covalent intermediate (ligaseadenylate), in which AMP is linked by a phosphoamide bond to the $\varepsilon$-amino group of a lysine (Doherty and Suh 2000). Thereafter, AMP is transferred to the 5'-end of the 5'-phosphate-terminated DNA strand to form DNA adenylate. In the final step, the DNA ligase catalyzes the attack of the nick on the DNA-adenylate by the 3'-OH to join the two polynucleotides and releases AMP (Doherty and Suh 2000).

As the third domain of the tree of life, archaea are similar to eukarya in many aspects of DNA metabolism while they are similar to bacteria in cellular morphology and structure (Edgell and Doolittle 1997; Olsen and Woese CR 1997). Currently, almost 2000 archaeal genomes are sequenced, and most can encode putative ATPdependent DNA ligases. Since the first biochemical description of the ATP-dependent DNA ligase from the thermophilic euryarchaeon Methanobacterium thermoautotrophicum (Sriskanda et al. 2000), dozens of archaeal DNA ligases have 
been reported (Tanabe et al. 2015). Most of the thermostable archaeal DNA ligases from thermophiles are capable of sealing nicks in an ATP-dependent manner at the high-temperature i which the host organisms thrive in. Biochemical data suggest that several archaeal DNA ligases exhibit distinct requirements for nucleotide cofactors, capable of utilizing $\mathrm{NAD}^{+}$, dATP, GTP or ADP as a cofactor (Jeon and Ishikawa 2003; Nakatani et al. 2000; Kim et al. 2006; Rolland et al. 2004; Seo et al. 2007).

Compared with their mesothermic counterparts, thermostable DNA ligases from hyperthermophiles are key components in the ligase chain reaction (LCR) for amplification and detection of single-base genetic diseases (Barany 1991; Qi et al. 2001). In addition, thermostable DNA ligases have important application potential in single nucleotide polymorphism (SNP) genotyping (Qi et al. 2001), since preferential ligation of matched base pairs by DNA ligases provides molecular basis of SNP determination (Wang et al. 2013; Li et al. 2005; Li et al. 2006; Pack et al. 2010). Thus, thermostable DNA ligases are powerful tools in molecular biology.

Since hyperthermophilic archaea inhabit high-temperature environments, their genomes are facing severe challenges due to increased deamination and depurination of DNA (van Wolferen et al. 2013; Lindahl and Nyberg 1974). However, with regards to their spontaneous mutation frequencies they resemble mesophiles (Grogan et al. 2001; Jacobs and Grogan 1997). Thus, they are supposed to express more efficient DNA repair capabilities than mesophilic organisms to counteract the increased mutation rates induced by high temperature. As a vital component in the DNA repair system, thermostable DNA ligases from hyperthermophilic archaea play essential roles in sealing nicks at high temperature.

Thermococcales represent one of the largest and best known class of Archaea thriving in hyperthermophilic environments, such as deep-sea hydrothermal vents and hot springs. Thermococcales are ubiquitous, and distributed worldly. Increasing numbers of Thermococcus species have been isolated and studied. Among them, strain Ch5 is a new member of the piezophilic and hyperthermophilic Thermococcus barophilus, isolated from a deep-sea hydrothermal field of the Mid-Atlantic Ridge 
(Logachev field chimney, 3,020 m depth) (Kim et al. 2010). As all members of this species, T. barophilus Ch5 is piezophilic, with optimal growth conditions of $85^{\circ} \mathrm{C}$ and $40 \mathrm{MPa}$ pressure (Marteinsson et al. 1999), and is capable of growing up to $100^{\circ} \mathrm{C}$. The sequence of the T. barophilus Ch5 genome shows that it encodes a putative DNA ligase. In this study, we cloned this gene, overexpressed the gene in E. coli, purified the recombinant protein and characterized its enzymatic properties. Our data demonstrate that the Tba ligase exhibits an optimal DNA ligation activity at $65-70^{\circ} \mathrm{C}$. Due to strong thermo-tolerance and mismatch discrimination, the Tba ligase might be used to perform LCR, with potential application in SNP genotyping. Surprisingly, the Tba ligase differs from almost all known ligases since it does not require additional nucleotide cofactor (NTPs or NAD ${ }^{+}$) to ligate nicked DNA.

\section{Materials and methods}

\section{Cloning, expression and purification of Tba ligase}

Strain Ch5 is available from the UBO Culture Collection (accession number: UBOCC-M-3206). The genome of T. barophilus Ch5 encodes a putative DNA ligase (TBCH5v1_RS10985). The genomic DNA of strain Ch5 was prepared as described by Oger et al. (2016). Using genomic DNA of strain Ch5 as a template, a PCR reaction was performed by Pfu DNA polymerase (Thermo Scientific, Waltham, MA, USA) to amplify the gene encoding Tba ligase in the presence of two primers (Table 1) and dNTPs. The amplified PCR product was cloned into vector pET-30a $(+)$ (Novagen, Merck, Darmstadt, Germany). The recombinant plasmid carrying the Tba ligase gene was sequenced to verify the absence of mutation, and then transformed into Escherichia coli BL21 (DE3) RIL cells (Transgene, Beijing, China) for protein overexpression.

The expression strain was inoculated into LB medium containing $100 \mu \mathrm{g} / \mathrm{mL}$ kanamycin and $34 \mu \mathrm{g} / \mathrm{mL}$ chloramphenicol, and shaken at $37^{\circ} \mathrm{C}$ until the $\mathrm{OD}_{600}$ reached 0.6. And then, isopropyl thiogalactoside (IPTG) was added into to the culture at a final concentration of $1 \mathrm{mM}$. The culture was continuously shaken at room temperature for another 10 hours until the $\mathrm{OD}_{600}$ exceeded 1.2. The culture was 
harvested by centrifugation $(5,000 \times \mathrm{g}, 10 \mathrm{~min})$ and resuspended in Ni column buffer A containing $20 \mathrm{mM}$ Tris- $\mathrm{HCl}(\mathrm{pH} 8.0), 1 \mathrm{mM}$ dithiothreitol (DTT), $500 \mathrm{mM} \mathrm{NaCl}$, $50 \mathrm{mM}$ imidazole, and $10 \%$ glycerol. The lysate was disrupted by ultrasonication in an ice-bath. The soluble proteins were separated from the cell debris by centrifugation $\left(16,000 \times \mathrm{g}, 20 \mathrm{~min}, 4^{\circ} \mathrm{C}\right)$. The supernatant was heated at $70^{\circ} \mathrm{C}$ for $20 \mathrm{~min}$ to remove non-thermostable proteins in E.coli. Following further centrifugation $(16,000 \times \mathrm{g}, 20$ $\min , 4^{\circ} \mathrm{C}$ ), the supernantant was filtered through a $0.22 \mu \mathrm{m}$ membrane and then applied to a HisTrap FF column (GE Healthcare, Uppsala, Sweden) and eluted with the $\mathrm{NCG}^{\mathrm{TM}}$ Chromatography System (Bio-Rad, Hercules, CA, USA) using a linear gradient of 50-500 mM imidazole. Fractions were analyzed by running a 10\% sodium dodecyl sulfate polyacrylamide gel electrophoresis and staining with coomassie brilliant blue to determine the purity of the Tba ligase protein. The purified Tba ligase fractions were collected and dialyzed in a storage buffer containing $50 \mathrm{mM}$ Tris-HCl (pH 8.0), $1 \mathrm{mM}$ DTT and 50\% glycerol, and stored at $-80^{\circ} \mathrm{C}$. The protein concentration was measured by using a Bradford Protein Assay Kit (Bio-Rad, Hercules, CA, USA).

\section{Construction, overexpression and purification of the Tba ligase K250A mutant}

A mutant plasmid with a K250A substitution was engineered using a Sitedirected Mutagenesis Kit (Transgene, China) and using the plasmid harboring the wild-type Tba ligase gene as a template according to manufacturer instructions. The targeted conserved acidic aminoacid residue, e.g. K250, is located in the conserved motif I of the Tba ligase (Fig. 1A). The sequences of the mutagenic primers are listed in Table 1. The desired mutation was confirmed by sequencing. The K250A mutant protein were overexpressed, purified and quantified, following the same protocols as described above for the wild-type enzyme.

\section{Preparation of two types of nicked DNA substrates}

Plasmid pET-30a (+) DNA can be nicked by GVE2 HNH endonuclease (Zhang et al. 2016). Thus, the nicked plasmid pET-30a (+) DNA was prepared in the DNA nicking reaction containing $200 \mathrm{ng}$ plasmid pET-30a (+) DNA, $20 \mathrm{mM}$ Tris- $\mathrm{HCl}(\mathrm{pH}$ 
8.0), $5.0 \mathrm{mM}$ DTT, $200 \mathrm{nM}$ GVE2 HNH endonuclease, $1.0 \mathrm{mM} \mathrm{MgCl}_{2}$ and $10 \%$ glycerol. The reactions were kept at $60^{\circ} \mathrm{C}$ for $3 \mathrm{~min}$ to ensure maximum yield of the nicked DNA. The nicked DNA product was purified by using a Cycle Pure Kit (Omega Bio-Tek, Norcross, GA, USA).

As shown in Table 1, the Cy3-labeled nucleotide duplex (*p22-37/t59) with a single nick was prepared by annealing the Cy3-labeled nucleotide $\left({ }^{*}\right.$ p22) and the phosphorylated nucleotide (p37) with the complementary nucleotide (t59) in a buffer containing $20 \mathrm{mM}$ Tris- $\mathrm{Cl}(\mathrm{pH} 8.0)$ and $100 \mathrm{mM} \mathrm{NaCl}$. The mixture was heated at $100^{\circ} \mathrm{C}$ for $5 \mathrm{~min}$ and cooled slowly at least 4 hours to room temperature.

\section{DNA ligation assays}

DNA ligation assays were conducted by incubating the enzyme with the nicked pET-30a (+) (200 ng) in the reactions $(10 \mu \mathrm{L})$ containing $20 \mathrm{mM}$ Tris- $\mathrm{HCl}(\mathrm{pH} 8.0)$, $5.0 \mathrm{mM}$ DTT, $1.0 \mathrm{mM} \mathrm{MgCl} 2,0.1 \mathrm{mg} / \mathrm{ml} \mathrm{BSA}, 8 \%$ glycerol, wild-type or $\mathrm{K} 250 \mathrm{~A}$ mutant Tba ligase with varied concentrations at $65^{\circ} \mathrm{C}$ for $10 \mathrm{~min}$, unless otherwise specified. The reactions were stopped by the addition of $10 \mu \mathrm{L}$ of $20 \mathrm{mM}$ EDTA. The samples were analyzed by electrophoresis in a $0.7 \%$ agarose gel. The efficiency of the Tba ligase was estimated by the difference between the cccDNA (ccc: covalently closed circle) percentage of product and the cccDNA percentage of substrate.

Considering the stability of the nicked nucleotide duplex, all the ligation reactions using it $(500 \mathrm{nM})$ as the substrate were performed with the same buffer as described above at $60^{\circ} \mathrm{C}$ for $10 \mathrm{~min}$. The reactions were stopped by the addition of 10 $\mu \mathrm{L}$ of stop solution containing $98 \%$ formamide and $20 \mathrm{mM}$ EDTA. The samples were heated at $100^{\circ} \mathrm{C}$ for $5 \mathrm{~min}$ and chilled rapidly on ice for $5 \mathrm{~min}$, and then loaded onto a denaturing $15 \%$ polyacrylamide gel containing $8 \mathrm{M}$ urea. After electrophoresis, the gels were scanned and Cy3-labeled DNA was visualized with a Molecular Image analyzer (PharosFx System, BioRad). ImageQuant software was used for quantitative analysis. All DNA ligation assays were performed in triplicates.

\section{Effect of reaction temperature on Tba ligase activity}

To determine the effect of reaction temperature on Tba ligase activity, the DNA 
ligation assays were performed at various temperatures $(35,40,45,50,55,60,65,70$, 75 and $80^{\circ} \mathrm{C}$ ) for $10 \mathrm{~min}$ using the nicked plasmid as a substrate. Samples were treated as described above.

\section{Thermo-tolerance assays}

To evaluate the enzyme's thermo-tolerance, Tba ligase was heated at 90, 95 and $100^{\circ} \mathrm{C}$ for $30 \mathrm{~min}$. In addition, the enzyme was heated at $100^{\circ} \mathrm{C}$ for $1,2,3$ and 4 hours. Then the heated Tba ligase was employed to perform DNA ligation assays at $65^{\circ} \mathrm{C}$ for $2,5,10$, or 15 min using the nicked plasmid as substrate. Samples were treated as described above.

\section{Effect of various divalent metal ions on Tba ligase activity}

To examine the effect of various divalent metal ions on Tba ligase activity, DNA ligation assays were performed in the presence of $\mathrm{Ca}^{2+}, \mathrm{Mg}^{2+}, \mathrm{Zn}^{2+}, \mathrm{Mn}^{2+}, \mathrm{Ni}^{2+}, \mathrm{Co}^{2+}$, $\mathrm{Fe}^{2+}$ or $\mathrm{Cu}^{2+}$ with varied concentrations $(0.1-2.0 \mathrm{mM})$ using the nicked plasmid as substrate. Alternatively, the nicked duplex was used as substrate to perform DNA ligation of the enzyme in the presence of $2.0 \mathrm{mM}$ of above divalent metal ions. Samples were treated as described above.

\section{Effects of pH and salinity on Tba ligase activity}

To investigate the effect of $\mathrm{pH}$ on Tba ligase activity, the DNA ligation reactions were performed under varied $\mathrm{pH}$ levels ranging from 4.0 to 10.0 . The reaction $\mathrm{pHs}$ were prepared using various buffers: acetate-sodium acetate for $\mathrm{pHs}=4.0$ and 5.0; sodium phosphate- $\mathrm{NaOH}$ for $\mathrm{pHs}=6.0$ and 7.0; Tris- $\mathrm{HCl}$ for $\mathrm{pH}=8.0$; $\mathrm{Gly}-\mathrm{NaOH}$ for $\mathrm{pHs}=9.0$ and 10.0. Samples were treated as described above. To determine the effect of salinity on Tba ligase activity, $\mathrm{NaCl}$ was added at various final concentrations (5$400 \mathrm{mM}$ ) to the DNA ligation reactions. Samples were treated as described above.

\section{Effects of various nucleotide cofactors on Tba ligase activity}

To probe the effects of nucleotide cofactors on Tba ligase activity, we added 1.0 mM ATP, CTP, UTP, GTP, dATP, dCTP, dGTP, dTTP or NAD ${ }^{+}$in DNA ligation reactions. Samples were treated as described above.

\section{NanoLC-MS/MS analysis}

The purified Tba ligase was separated by electrophoresis in a $10 \%$ native 
polyacrylamide gel. The gel was stained with coomassie brilliant blue, and destained with methanol and ethanol. The gel containing the protein samples was cut into small pieces. The gel pieces were swollen in a digestion buffer containing $50 \mathrm{mM}$ $\mathrm{NH}_{4} \mathrm{HCO}_{3}, 12.5 \mathrm{ng} / \mathrm{uL}$ of trypsin in an ice-cold bath. After 1 hour in an ice-cold bath, the supernatant was removed and replaced with $50 \mathrm{mM} \mathrm{NH}_{4} \mathrm{HCO}_{3}$, without trypsin, to keep the gel pieces wet during enzymic cleavage $\left(37^{\circ} \mathrm{C}, 16\right.$ hours $)$. The digested products were lyophilized to dryness.

The dried peptides were dissolved in $0.1 \%$ formic acid ( $/ \mathrm{v})$ and subjected to an EASY-nLC 1000 interfaced via a Nanospray Flex ion source to Orbitrap Fusion Tribrid mass spectrometer (Thermo Fisher Scientific). The peptides were loaded onto a trap column (C18, $5 \mu \mathrm{m}$ particles, $100 \mu \mathrm{m}$ ID, $2 \mathrm{~mm}$ length, Dr. Maisch GmbH) and separated using an analytical column $(\mathrm{C} 18,3 \mu \mathrm{m}$ particles, $75 \mu \mathrm{m}$ ID, $15 \mathrm{~mm}$ length, Dr. Maisch $\mathrm{GmbH}$ ) at a flow rate of $400 \mathrm{~nL} / \mathrm{min}$ with a $30 \mathrm{~min}$ LC gradient composed of Solvent A (0.1\% formic acid (v/v)) and Solvent B (acetonitrile,0.1\% formic acid (v/v)). The gradient was 3-8\% B for $2 \mathrm{~min}, 8-25 \%$ B for $20 \mathrm{~min}, 25-60 \%$ B for $5 \mathrm{~min}$, $60-80 \%$ B for $1 \mathrm{~min}$, and finally $80 \%$ B for $2 \mathrm{~min}$. A data-dependent method was used

with precursor MS1 scan (m/z 350-1550) acquired in the Orbitrap at a resolution setting of 120,000, followed by Orbitrap HCD-MS/MS, EThcD-MS/MS and CIDMS/MS of the 15 most abundant multiply charged precursors in the MS1 spectrum. MS2 spectra were acquired at a resolution of 30,000 .

\section{Effect of mismatches on DNA ligation by Tba ligase}

To uncover the effect of mismatches adjacent to the nick on DNA ligation, we used the nicked nucleotide duplexes with mismatches as substrates to examine Tba ligase activity. The mismatches $(\mathrm{A} / \mathrm{C}, \mathrm{C} / \mathrm{C}$ or $\mathrm{T} / \mathrm{C})$ were located in both $3^{\prime}$ and $5^{\prime}$ of the nick. The annealed nucleotide duplexes were incubated with $800 \mathrm{nM}$ Tba ligase at $60^{\circ} \mathrm{C}$ for $10 \mathrm{~min}$ in an optimal buffer. Samples were treated as described above.

\section{Ligation chain reaction by Tba ligase}

Ligation chain reaction (LCR) was performed in a reaction mixture $(20 \mu \mathrm{L})$ 
containing $20 \mathrm{mM}$ Tris-HCl (pH 8.0), $1.0 \mathrm{mM} \mathrm{MgCl} 2,5.0 \mathrm{mM}$ DTT, $0.1 \mathrm{mg} / \mathrm{mL}$ BSA, and $800 \mathrm{nM}$ Tba ligase in the presence of a double stranded, nicked oligonucleotide composed of a Cy3-labeled nucleotides (*p22), a phosphorylated nucleotide (p37), and the complementary nucleotide (t59) as described above. The LCR thermal cycling was initialized by preheating at $95^{\circ} \mathrm{C}$ for $3 \mathrm{~min}$, followed by 10 cycles containing denaturation at $95^{\circ} \mathrm{C}$ for $30 \mathrm{~s}$, ligation at $60^{\circ} \mathrm{C}$ for $1 \mathrm{~min}$, with a final 5 min ligation step at $60^{\circ} \mathrm{C}$. Samples were treated as described above.

\section{Results}

\section{The genome of T. barophilus Ch5 encodes a putative DNA ligase}

The putative Tba ligase possesses all six conserved sequence motifs typical of ATP-dependent DNA ligases (Fig. 1A) which exist in euryarchaea, crenarchaea, eukarya and phages. The conserved lysine residue in Motif I of ATP-dependent DNA ligases plays an important role in binding AMP for DNA ligation (Doherty and Suh 2000). Thus, we hypothesized that Tba ligase might be ATP-dependent.

To probe the biochemical characteristics of the putative DNA ligase from $T$. barophilus strain Ch5, the Tba ligase gene was cloned into the pET-30a (+) expression vector, and expressed in the E. coli BL21 (DE3) cells. The recombinant Tba ligase protein was successfully expressed in the E.coli cells after the addition of IPTG (Fig. 1B). The enzyme was further purified near homogeneity after sonic disruption, heat treatment and Ni-column affinity purification (around $63 \mathrm{kDa}$ ) (Fig. 1B). Using nicked plasmid as a substrate, we probed the effect of enzyme concentration on Tba ligase activity. We found that the ligation efficiency increased with increasing Tba ligase concentration, exhibiting a maximum at $400 \mathrm{nM}$ or more (Fig. 1C). Thus, Tba ligase is capable of joining the nicked DNA at $65^{\circ} \mathrm{C}$. Using nicked nucleotide duplex as substrate, Tba ligase was able to join $94 \%$ of the product (Fig. 1D), and displayed maximal activity at concentrations over $800 \mathrm{nM}$.

Although the heat treatment at $70^{\circ} \mathrm{C}$ for $30 \mathrm{~min}$ should have inactivated the $E$. coli DNA ligase, there was still a possibility of contamination by this ligase during the purification of the Tba ligase, which would affect our observations. To exclude this 
possibility, we used the E.coli lysate expressing the empty plasmid to perform the same DNA ligation reactions. No ligated DNA product was formed by the E.coli lysate (Fig. S1). In addition, we constructed the K250A mutant of Tba ligase in which we introduced a mutation in the active domain, and expressed and purified the mutant protein as described for the wild-type protein (Fig. S2). Again, no ligated DNA was produced by the K250A mutant (Fig. S3) confirming quite clearly that E. coli DNA ligase contamination could be ruled out, and that Tba ligase is capable of sealing nicks.

\section{Tba ligase can ligate nicks at high temperature}

Since strain Ch5 is a hyperthermophilic archaeon, we first determined the temperature range of for the activity of the enzyme using the nicked plasmid as a substrate. As shown in Fig. 2A, no significant change in ligation efficiency was observed when the ligation reactions were performed from $35^{\circ} \mathrm{C}$ to $45^{\circ} \mathrm{C}$. As the reaction temperature increased from $50^{\circ} \mathrm{C}$ to $80^{\circ} \mathrm{C}$, Tba ligase displays varied ligation efficiencies. Ligation efficiencies reached a maximum when reaction temperatures were $65^{\circ} \mathrm{C} \sim 70^{\circ} \mathrm{C}$, (Fig. 2A). Thus, the optimal reaction temperature of Tba ligase activity is $65^{\circ} \mathrm{C} \sim 70^{\circ} \mathrm{C}$.

Furthermore, we found that the heated Tba ligase at 90,95 , and $100^{\circ} \mathrm{C}$ for $30 \mathrm{~min}$ had similar ligation efficiencies to the unheated control enzyme (Fig. 2B). These results show that the enzyme can withstand $100^{\circ} \mathrm{C}$ for 30 min without any loss of ligation activity. To further investigate its thermo-tolerance, we heated the enzyme at $100^{\circ} \mathrm{C}$ for various time ranging from 1 hour to 4 hours. Compared with the unheated enzyme, the heated Tba ligase displayed clearly reduced ligation efficiency at $100^{\circ} \mathrm{C}$ for 3 hour or more (Fig. 2C). However, the enzyme retained pronounced ligation efficiency when heated at $100^{\circ} \mathrm{C}$ for 2 hours (Fig. 2C). Taken together, these results suggest that Tba ligase is a highly thermostable enzyme.

\section{Effect of divalent metal ions on Tba ligase activity}

Here, we investigated the dependence of Tba ligase activity for various divalent metal ions $\left(\mathrm{Mg}^{2+}, \mathrm{Mn}^{2+}, \mathrm{Fe}^{2+}, \mathrm{Cu}^{2+}, \mathrm{Ca}^{2+}, \mathrm{Zn}^{2+}, \mathrm{Ni}^{2+}\right.$ or $\left.\mathrm{Co}^{2+}\right)$. In the presence of $10 \mathrm{mM}$ 
EDTA that might chelate completely any divalent metal ion co-purified during protein purification, no ligation product was formed by the enzyme (Figs. 3A, 3B and 3C), suggesting that the enzyme is effectively dependent on a divalent metal ion. As shown in Fig. 3A, Tba ligase was active in presence of $2 \mathrm{mM} \mathrm{Mg}^{2+}, \mathrm{Mn}^{2+}$ or $\mathrm{Ca}^{2+}$, but inactive in presence of $\mathrm{Mg}^{2+}, \mathrm{Mn}^{2+}$ or $\mathrm{Ca}^{2+}$ at lower concentrations (0.1 and $0.5 \mathrm{mM}$ ). Furthermore, the enzyme had no detectable activity in the presence of $\mathrm{Fe}^{2+}, \mathrm{Cu}^{2+}, \mathrm{Ni}^{2+}$, $\mathrm{Co}^{2+}$ or $\mathrm{Zn}^{2+}$ (Figs. 3A and 3B), regardless of the concentrations used.

When using nicked nucleotide duplex as substrate, the enzyme displayed about $36 \%$ ligation efficiency in absence of added divalent metal ion, suggesting that the enzyme contains potential divalent metal ions that can stimulate enzyme activity. In presence of $1.0 \mathrm{mM} \mathrm{Mg}^{2+}, \mathrm{Mn}^{2+}$ or $\mathrm{Ca}^{2+}$ yields higher than $95 \%$ were observed (Fig. 3C), confirming the preferred ions for Tba ligase activity. We also observed a weak activity with $\mathrm{Cu}^{2+}$, but no activity with $\mathrm{Fe}^{2+}, \mathrm{Ni}^{2+}, \mathrm{Co}^{2+}$ or $\mathrm{Zn}^{2+}$ (Fig. 3C). This demonstrates that the enzyme can utilize $\mathrm{Mg}^{2+}, \mathrm{Mn}^{2+}$ or $\mathrm{Ca}^{2+}$ as efficient cofactors.

\section{Optimal pH and $\mathrm{NaCl}$ of Tba ligase activity}

Using the nicked nucleotide duplex as substrate, no ligation product was observed only at $\mathrm{pH}=4.0$ (Fig. $4 \mathrm{~A}$ ), while the enzyme showed $49 \%$ and $45 \%$ ligation activity at $\mathrm{pH}=5$ and $\mathrm{pH}=10$ (Fig. 4A), respectively. For $\mathrm{pHs}$ ranging from 6 to 9 , the ligation efficiencies of the enzyme were maximal (>95\%) (Fig. 4A). The Tba ligase displays a similar $\mathrm{pH}$ adaptation using the nicked plasmid as substrate (Fig. 4B). Thus, the $\mathrm{pH}$ range of Tba ligase is wide $(5 \sim 10)$, and the optimal $\mathrm{pH}$ of the enzyme is between $\mathrm{pH}$ 6-9.

In the absence of $\mathrm{NaCl}$, the ligation efficiencies of Tba ligase was $>95 \%$ (Fig. 4C), suggesting that the ligation activity of the enzyme is independent of $\mathrm{NaCl}$. The activity was not affected at low $\mathrm{NaCl}$ concentrations $(5-50 \mathrm{mM})$, but started to be reduced to $89 \%$ and $58 \%$ activity at $100 \mathrm{mM}$ and $200 \mathrm{mM} \mathrm{NaCl}$ (Fig. 4C), respectively. $400 \mathrm{mM} \mathrm{NaCl}$ completely abolished the ligation activity (Fig. 4C). Tba ligase exhibited a similar $\mathrm{NaCl}$ adaptation using the nicked plasmid as substrate (Fig. 4D), Thus, Tba ligase activity is suppressed by $\mathrm{NaCl}$ with high concentrations. 


\section{Dependence of Tba ligase on nucleotide cofactors}

As described above, most reported archaeal DNA ligases are dependent on nucleotide cofactors to drive DNA ligation. Here, we investigated the effect of nucleotide cofactors including NTPs, dNTPs or $\mathrm{NAD}^{+}$on Tba ligase activity. We showed that ATP is the cofactor required for optimal activity of the Tba ligase. Indeed, nicked DNA was completely ligated in presence of 1mM ATP (Figs. S3 and S4). $\mathrm{NAD}^{+}$had no effect on Tba ligase activity (Fig. S3), suggesting that the enzyme cannot use NAD ${ }^{+}$as a cofactor. To the exception of UTP, none of the of dNTPs and NTPs could be used by the enzyme as a cofactor (Fig. S5). UTP weakly stimulated the activity of Tba ligase (Fig. S5). Surprisingly, in the control reaction performed with high concentrations of the Tba ligase but without addition of any nucleotide cofactor, we found that the enzyme was active nonetheless (Fig. 5A and 5B), suggesting that the enzyme could fonction without additional nucleotide cofactor. Thus, as expected from the sequence data, the Tba ligase is an ATP-dependent DNA ligase, which can also accept UTP as a weak cofactor. Confirming this hypothesis, our mass spectrometric result shows that the K250 residue is AMPlyated (Fig. 6), showing that the purified enzyme is bound to AMP.

\section{Kinetics of Tba ligase activity}

We determined the kinetics of DNA joining by Tba ligase under the optimal reaction condition containing $200 \mathrm{ng}$ nicked plasmid, $500 \mathrm{nM}$ enzyme, $2.0 \mathrm{mM} \mathrm{Mg}^{2+}$, and $\mathrm{pH}$ 8.0. The ligation yield of the enzyme increased as the reaction time extended. Maximum efficiency was observed for reaction time was over $60 \mathrm{~min}$ (Fig. 7A). Much shorter times were necessary when using a singly nicked DNA as DNA substrate, since maximum ligation efficiency was reached after $20 \mathrm{~min}$ (Fig. 7B). Thus, Tba ligase showed better ligation efficiency with singly nicked duplex compared to nicked plasmid as substrate.

\section{Effect of mismatches on Tba ligase activity}

To test the impact of mismatches in the sequence adjacent to the nick, we synthesized various nucleotides (Fig. 8A). Mismatches adjacent to $3^{\prime}$ terminal of the nick had the greatest impact on ligation efficiency by the Tba ligase, exhibiting only 
$10 \%, 11 \%$ and $28 \%$ of efficiency respectively for the $\mathrm{A} / \mathrm{C}, \mathrm{C} / \mathrm{C}$ and $\mathrm{T} / \mathrm{C}$ in comparison to the matched G/C (Fig. 8B). However, ligation efficiencies were estimated to be $80 \%, 39 \%$ and $86 \%$ when the $\mathrm{A} / \mathrm{C}, \mathrm{C} / \mathrm{C}$ and $\mathrm{T} / \mathrm{C}$ mismatches were adjacent to $5^{\prime}$ terminal of the nick (Fig. 8B), respectively. These results suggest that the Tba ligase is more tolerant to mismatches adjacent to $5^{\prime}$ terminal of the nick than to mismatches adjacent to $3^{\prime}$ terminal of the nick. Furthermore, since Tba ligase can effectively discriminate mismatches, the enzyme could be potentially used in SNP assays.

\section{LCR by Tba ligase}

Since the Tba ligase is more sensitive to mismatches adjacent to the 3 '-terminal of the nick than to the 5'-terminal of the nick (Fig. 8B), we proposed that the enzyme can be useful to perform LCR due to its high thermostability. We set up LCR reactions using various nucleotides harboring matched and mismatched DNA substrates and a nick. As shown in Fig. 9, the Tba ligase displayed almost 100\% of LCR efficiencies when using matched, nicked DNA. As expected, the ligase displayed the same LCR efficiency with 5' mismatched, nicked DNA templates as with matched templates. In contrast, the LCR efficiency of the enzyme was estimated to be $18 \%, 14 \%$, and $53 \%$ in the presence of $\mathrm{C}: \mathrm{A}, \mathrm{C}: \mathrm{C}$ and $\mathrm{C}: \mathrm{T}$ mismatches at the $3^{\prime}$ terminal of the nick, respectively. These observations confirms that the Tba ligase can only discriminate mismatches at the $3^{\prime}$ side of the nick, which is consistent with the observation that the enzyme is more sensitive to mismatches adjacent to the $3^{\prime}$-terminal of the nick than the $5^{\prime}$-terminal of the nick.

\section{Discussion}

In this work, we cloned the gene encoding a putative DNA ligase from the hyperthermophilic archaeon T. barophilus Ch5, purified the recombinant protein, and biochemically characterized the enzyme using two substrates: nicked plasmid and nicked nucleotide duplex. Since DNA ligases from thermophiles are thermostable, we first revealed the optimal temperature and thermo-tolerance of Tba ligase by using a nicked plasmid. The nicked plasmid is a better DNA substrate for determining DNA ligation at high temperature than the nicked nucleotide duplexes since the former is 
more stable. Our data suggest that Tba ligase has an optimal activity at $65-70^{\circ} \mathrm{C}$, similar to the reported DNA ligases from hyperthermophilic crenarchaea and euryarchaea: Methanobacterium thermoautotrophicum (Sriskanda et al. 2000), Aeropyrum pernix (Jeon and Ishikawa 2003), Thermococcus kodakaraensis KOD1 (Nakatani et al. 2000), Thermococcus sp. (Kim et al. 2006), Thermococcus fumicolans (Rolland et al. 2004), Staphylothermus marinus (Seo et al. 2007), Hyperthermus butylicus (Kim et al. 2013), Sulfophobococcus zilligii (Sun et al. 2008), Sulfolobus shibatae (Lai et al. 2002) and Pyrococcus horikoshii (Keppetipola and Shuman 2005). Only one DNA ligase from a hyperthermophile Methanocaldococcus jannaschii displays its optimal activity at a lower temperature $\left(52.5-55^{\circ} \mathrm{C}\right)$ (Wang et al. 2013). Overall, DNA ligases from thermophiles are capable of joining DNA at high temperature.

Tba ligase is one of the most thermostable DNA ligase described so far. Indeed, hyperthermophilic archaeal DNA ligases display much variation in thermo-tolerance. 30 min at $90^{\circ} \mathrm{C}$ essentially abolishes $M$. jannaschii DNA ligase activity (Wang et al. 2013), while those of S. shibatae and A. pernix can withstand heat treatment up to 1 hour at $95^{\circ} \mathrm{C}$ (Lai et al. 2002) or $100^{\circ} \mathrm{C}$ (Jeon and Ishikawa 2003). In this work, we found that the Tba ligase still retains activity even after more than 2 hours at $100^{\circ} \mathrm{C}$, similar to the observations of the half-life of $S$. marinus ligase $\left(2.8\right.$ hours at $\left.100^{\circ} \mathrm{C}\right)$ (Seo et al. 2007).

Archaeal DNA ligases exhibit very diverse nucleotide cofactor requirements. $S$. marinus and M. thermoautotrophicum DNA ligases utilize ATP as nucleotide cofactor, and dATP as a weak effector (Sriskanda et al. 2000; Kim et al. 2013). DNA ligases from T. fumicolans (Rolland et al. 2004), T. kodakaraensis KOD1 (Nakatani et al. 2000), and P. abyssi (Zakabunin et al. 2011), which are phylogenetically closely related to T. Barophilus, and Haloferax volcanii (Zhao et al. 2006) can utilize NAD ${ }^{+}$ as a nucleotide cofactor, as well as ATP. Moreover, DNA ligases from S. shibatae and S. marinus are dependent on ATP/ADP to seal nicks (Lai et al. 2002; Seo et al. 2007). ADP, GTP and ATP can be used as a nucleotide cofactor to drive H. butylicus and $S$. 
zilligii DNA ligases to seal DNA nicks (Kim et al. 2013; Sun et al. 2008). The A. pernix DNA ligase can utilize $\mathrm{NAD}^{+}$, $\mathrm{ATP}$ or ADP to ligate DNA. The Tba ligase is also an ATP-dependent ligase which can use UTP for its activity. Our results also showed that the Tba ligase could also be active in absence of externally added nucleotide cofactors, as was shown for the P. furiosus DNA ligase (Nishida et al. 2006). This is consistent with the use of the AMP molecule bound to the protein to perform the activity. In absence of ATP, the protein is subsequently not restored to its functional for, explaining why this phenomenom is observed only when high concentrations of Tba ligase are used.

A previous study has shown that the two basic residues (R531 and K534) in the RDDK motif in the P. furiosus DNA ligase played a key role in the binding of AMP (Nishida et al. 2006). Our results show that in the Tba ligase AMP is linked to residue $\mathrm{K} 250$ which is part of the conserved motif $\mathrm{I}$, suggesting that the enzyme is bound to AMP. As mentioned above, ATP is required for Tba ligase activity at low concentration. Thus, Tba ligase is another example of an ATP-dependent ligase, for which activity requires no additional ATP at high concentrations.

Most Archaeal DNA ligases display activity in a similar range of $\mathrm{pH}$. In this work, we found that the Tba ligase is active over a wide $\mathrm{pH}$ spectrum (5-10) with an optimum between pH 6 and 9, similar to what is reported for most archaeal DNA ligases. Indeed, the optimal pHs of DNA ligases of M. jannaschii (Wang et al. 2013), Ferroplasma acidarmanus (Jackson et al. 2007), H. butylicus (Kim et al. 2006), T. sp (Jeon and Ishikawa 2003), A. pernix (Jeon and Ishikawa 2003) and S. marinus (Seo et al. 2007) are 8.5, 6-7, 8.0, 7.5, 7.5 and 6.5.

Most of DNA ligases are dependent on a divalent metal ion to seal nicks, among which $\mathrm{Mg}^{2+}$ is a common divalent metal ion. However, some DNA ligases are capable of utilizing alternative metal cofactors to catalyze DNA ligation. We found that a divalent metal ion is needed for Tba ligase, and both $\mathrm{Mn}^{2+}$ and $\mathrm{Ca}^{2+}$ can enable the enzyme to ligate DNA with maximum efficiencies, as well as $\mathrm{Mg}^{2+}$. However, $\mathrm{Ca}^{2+}$ inhibits the activities of S. marinus and F. acidarmanus DNA ligases (Seo et al. 2007; 
Jackson et al. 2007). Similar to Tba ligase, A. pernix, S. shibatae and M. jannaschii DNA ligases are active in the presence of $\mathrm{Ca}^{2+}$ (Jeon and Ishikawa 2003; Jeon and Ishikawa 2003; Wang et al. 2013).

The Tba ligase is inactive with $\mathrm{Ni}^{2+}, \mathrm{Co}^{2+}, \mathrm{Zn}^{2+}$ or $\mathrm{Fe}^{2+}$. Other archaeal DNA ligases exhibit much variation in the utilization of $\mathrm{Ni}^{2+}, \mathrm{Co}^{2+}, \mathrm{Zn}^{2+}$ or $\mathrm{Fe}^{2+}$. T. sp DNA ligase is active with $\mathrm{Ni}^{2+}$ whereas A. pernix, F. acidarmanus, S. shibatae and $S$. marinus DNA ligases are inhibited by $\mathrm{Ni}^{2+}$ (Jeon and Ishikawa 2003; Seo et al. 2007; Lai et al. 2002; Jackson et al. 2007). In addition, $\mathrm{Cu}^{2+}$ slightly stimulates the Tba ligase activity, but suppresses DNA ligases from M. thermoautotrophicum, A. pernix, F. acidarmanus, S. shibatae and M. jannaschii (Sriskanda et al. 2000 ; Jeon and Ishikawa 2003; Wang et al. 2013; Lai et al. 2002; Jackson et al. 2007). As observed in Tba ligase, $\mathrm{Zn}^{2+}$ is also an inhibitor for DNA ligases from M. thermoautotrophicum, A. pernix, F. acidarmanus, S. shibatae, S. marinus and M. jannaschii (Sriskanda et al. 2000; Jeon and Ishikawa 2003; Seo et al. 2007), while it can stimulate the activity of the T. sp DNA ligase (Kim et al. 2006). Similar to Tba ligase, the activities of F. acidarmanus, S. shibatae, and M. jannaschii DNA ligases are suppressed by $\mathrm{Co}^{2+}$ (Wang et al. 2013; Lai et al. 2002; Jackson et al. 2007), but this ion is an activator for M. thermoautotrophicum and A. pernix DNA ligases (Sriskanda et al. 2000; Jeon and Ishikawa 2003). Overall, our results extend on the fact that archaeal DNA ligases have very distinct divalent metal ion requirements.

Archaeal DNA ligases show great variation in $\mathrm{NaCl}$ adaptation. M. jannaschii DNA ligase is inactive at $200 \mathrm{mM} \mathrm{NaCl}$ (Wang et al. 2013), whereas $M$. thermoautotrophicum and T. fumicolans DNA ligases have no ligation activity in the presence of $100 \mathrm{mM} \mathrm{NaCl}$ (Sriskanda et al. 2000; Rolland et al. 2004). We found that the Tba ligase can retain its activity in the presence of $200 \mathrm{mM} \mathrm{NaCl}$, but $400 \mathrm{mM}$ $\mathrm{NaCl}$ completely inhibits the enzyme activity. Thus, Tba ligase is more salt-tolerant than the M. jannaschii, M. thermoautotrophicum and T. fumicolans DNA ligases (Sriskanda et al. 2000; Rolland et al. 2004; Wang et al. 2013), but, no so surprisingly, is less salt-tolerant than the DNA ligase from the halophilic euryarchaeon $H$. volcanii 
(Poidevin and MacNeill 2006).

In this work, we present that Tba ligase is more sensitive to the mismatches on the 3 '-side than to those on the 5'-side, which is similar to DNA ligases I, II, and III from mammalian cells, S. shibatae and vaccinia DNA ligases (Lai et al. 2002; Shuman 1995; Chen et al. 1995). By contrast, the mismatch on the 5'-sides of the nick inhibits M. jannaschii DNA ligase activity (Wang et al. 2013). Remarkably, some viral ATP-dependent DNA ligases show tolerance of mismatches on both 3'- and 5'sides of the nick (Shuman 1995). Thus, DNA ligases from eukarya, bacteria, and viruses exhibit great variations in mismatch discrimination at the nick.

In addition to sealing DNA in recombinant technology, thermostable DNA ligases have been employed in single nucleotide polymorphism (SNP) genotyping because of their high base specificity in ligation (Barany 1991; Qi et al. 2001). Due to their high thermostability, thermostable DNA ligases from thermophiles display potential application in biotechnology. In this work, we present that Tba ligase can display various LCR efficiencies in the presence of C:A, C:C and C:T mismatches at the 3 ' terminal, thus implicating its potential application in SNP genotyping.

In summary, we characterized biochemically the recombinant DNA ligase from T. barophilus Ch5. Tba ligase is a highly thermostable and thermotolerant ligase, able to join DNA nicks at high temperature. The enzyme is bound to AMP, is independent of extragenous nucleotide cofactor, but ATP stimulates activity. The enzyme is sensitive to mismatches adjacent on the $3^{\prime}$ side of the nick, and almost insensitive to mismatches on the 5'-side. Furthermore, the enzyme can effectively discriminate mismatches in LCR, suggesting that it has a great potential for single nucleotide polymorphism assays.

\section{Acknowledgements}

This work was supported by the National Natural Science Foundation of China Grant (No. 41306131) to L.Z., the Academic Leader of Middle and Young People of Yangzhou University Grant to L.Z.; the practice innovation training program for college students in Yangzhou University to H.S. (No. XKYCX18_072); the National 
Natural Science Foundation of Jiangsu Province (No. BK20180937) to C.T.

\section{Conflict of interest}

All authors declare that they have no conflict of interest.

\section{Ethical Statement}

This article does not contain any studies with human participants or animals performed by any of the authors.

\section{Author contributions}

LZ, ZY and PO designed experiments; HS, YL, QG, YH, MR, HC and CT performed experiments; LZ, ZY, HS and YH analyzed data; LZ, ZY and PO wrote and revised the paper.

\section{References}

Barany F (1991) Genetic disease detection and DNA amplification using cloned thermostable ligase. Proc Natl Acad Sci U S A 88: 189-193

Chambers CR, Patrick WM (2015) Archaeal nucleic acid ligases and their potential in biotechnology. Archaea: 170571

Chen J, Tomkinson AE, Ramos W, Mackey ZB, Danehower S, Walter CA, Schultz RA, Besterman JM, Husain I (1995) Mammalian DNA ligase III: molecular cloning, chromosomal localization, and expression in spermatocytes undergoing meiotic recombination. Mol Cell Biol 15: 5412-5422

Doherty AJ, Suh SW (2000) Structural and mechanistic conservation in DNA ligases, Nucleic Acids Res 28: 4051-4058

Edgell DR, Doolittle WF (1997) Archaea and the origin(s) of DNA replication proteins. Cell 89: 995-998

Ellenberger T, Tomkinson AE (2008) Eukaryotic DNA ligases: structural and functional insights. Annu Rev Biochem 77: 313-338

Grogan DW, Carver GT, Drake JW (2001) Genetic fidelity under harsh conditions: analysis of spontaneous mutation in the thermoacidophilic archaeon Sulfolobus acidocaldarius. Proc Natl Acad Sci U S A 98: 7928-7933

Jackson BR, Noble C, Lavesa-Curto M, Bond PL, Bowater RP (2007) Characterization of an ATP-dependent DNA ligase from the acidophilic archaeon 
"Ferroplasma acidarmanus" Fer1. Extremophiles 11: 315-327

Jacobs KL, Grogan DW (1997) Rates of spontaneous mutation in an archaeon from geothermal environments. J Bacteriol 179: 3298-3303

Jeon SJ, Ishikawa K (2003) A novel ADP-dependent DNA ligase from Aeropyrum pernix K1. FEBS Lett 550: 69-73

Keppetipola N, Shuman S (2005) Characterization of a thermophilic ATP-dependent DNA ligase from the euryarchaeon Pyrococcus horikoshii, J Bacteriol 187: 6902-6908 Kim YJ, Lee HS, Kim ES, Bae SS, Lim JK, Matsumi R, Lebedinsky AV, Sokolova TG, Kozhevnikova DA, Cha SS, Kim SJ, Kwon KK, Imanaka T, Atomi H, BonchOsmolovskaya EA, Lee JH, Kang SG (2010) Formate-driven growth coupled with $\mathrm{H}(2)$ production. Nature 467: 352-355

Kim YJ, Lee HS, Bae SS, Jeon JH, Yang SH, Lim JK, Kang SG, Kwon ST, Lee JH (2006) Cloning, expression, and characterization of a DNA ligase from a hyperthermophilic archaeon Thermococcus sp. Biotechnol Lett 28: 401-407

Kim JH, Lee KK, Sun Y, Seo GJ, Cho SS, Kwon SH, Kwon ST (2013) Broad nucleotide cofactor specificity of DNA ligase from the hyperthermophilic crenarchaeon Hyperthermus butylicus and its evolutionary significance. Extremophiles 17: 515-522

Lai X, Shao H, Hao F, Huang L (2002) Biochemical characterization of an ATPdependent DNA ligase from the hyperthermophilic crenarchaeon Sulfolobus shibatae. Extremophiles 6: 469-477

Lehman IR (1974) DNA ligase: structure, mechanism, and function. Science 186: $790-797$

Li J, Chu X, Liu Y, Jiang JH, He Z, Zhang Z, Shen G, Yu RQ (2005) A colorimetric method for point mutation detection using high-fidelity DNA ligase. Nucleic Acids Res 33: e168

Li Y, Wark AW, Lee HJ, Corn RM (2006) Single-nucleotide polymorphism genotyping by nanoparticle-enhanced surface plasmon resonance imaging measurements of surface ligation reactions. Anal Chem 78: 3158-3164 Lindahl T, Barnes DE (1992) Mammalian DNA ligases. Annu Rev Biochem 61: 251- 
Lindahl T, Nyberg B (1974) Heat-induced deamination of cytosine residues in deoxyribonucleic acid. Biochemistry 13: 3405-3410

Marteinsson VT, Birrien JL, Reysenbach AL, Vernet M, Marie D, Gambacorta A, Messner P, Sleytr UB, Prieur D (1999) Thermococcus barophilus sp. nov., a new barophilic and hyperthermophilic archaeon isolated under high hydrostatic pressure from a deep-sea hydrothermal vent. Int J Syst Bacteriol 49: 351-359.

Nakatani M, Ezaki S, Atomi H, Imanaka T (2000) A DNA ligase from a hyperthermophilic archaeon with unique cofactor specificity. J Bacteriol 182: 64246433

Nishida H, Kiyonari S, Ishino Y, Morikawa K (2006) The closed structure of an archaeal DNA ligase from Pyrococcus furiosus. J Mol Biol 360: 956-967

Qi X, Bakht S, Devos KM, Gale MD, Osbourn A (2001) L-RCA (ligation-rolling circle amplification): a general method for genotyping of single nucleotide polymorphisms (SNPs). Nucleic Acids Res 29: e116

Oger P, Sokolova TG, Kozhevnikova DA, Taranov EA, Vannier P, Lee HS, Kwon KK, Kang SG, Lee JH, Bonch-Osmolovskaya EA, Lebedinsky AV (2016) Complete genome sequence of the hyperthermophilic and piezophilic archaeon Thermococcus barophilus $\mathrm{Ch} 5$, capable of growth at the expense of hydrogenogenesis from carbon monoxide and formate. Genome Announc 4 e01534-15

Olsen GJ, Woese CR (1997) Archaeal genomics: an overview. Cell 89: 991-994

Pack SP, Doi A, Choi YS, Kim HB, Makino K (2010) Accurate guanine:cytosine discrimination in T4 DNA ligase-based single nucleotide polymorphism analysis using an oxanine-containing ligation fragment. Anal Biochem 398: 257-259

Poidevin L, MacNeill SA (2006) Biochemical characterisation of LigN, an NAD ${ }^{+}$ dependent DNA ligase from the halophilic euryarchaeon Haloferax volcanii that displays maximal in vitro activity at high salt concentrations. BMC Mol Biol 7: 44 Rolland JL, Gueguen Y, Persillon C, Masson JM, Dietrich J (2004) Characterization of a thermophilic DNA ligase from the archaeon Thermococcus fumicolans. FEMS Microbiol Lett 236: 267-273 
Seo MS, Kim YJ, Choi JJ, Lee MS, Kim JH, Lee JH, Kwon ST (2007) Cloning and expression of a DNA ligase from the hyperthermophilic archaeon Staphylothermus marinus and properties of the enzyme. J Biotechnol 128: 519-530

Shuman S (1995) Vaccinia virus DNA ligase: specificity, fidelity, and inhibition. Biochemistry 34: 16138-16147

Shuman S (2009) DNA ligases: progress and prospects. J Biol Chem 284: $17365-$ 17369

Sriskanda V, Kelman Z, Hurwitz J, Shuman S (2000) Characterization of an ATPdependent DNA ligase from the thermophilic archaeon Methanobacterium thermoautotrophicum. Nucleic Acids Res 28: 2221-2228

Sun Y, Seo MS, Kim JH, Kim YJ, Kim GA, Lee JI, Lee JH, Kwon ST (2008) Novel DNA ligase with broad nucleotide cofactor specificity from the hyperthermophilic crenarchaeon Sulfophobococcus zilligii: influence of ancestral DNA ligase on cofactor utilization. Environ Microbiol 10: 3212-3224

Tanabe M, Ishino Y, Nishida H (2015) From structure-function analyses to protein engineering for practical applications of DNA ligase. Archaea: 267570

Tomkinson AE, Vijayakumar S, Pascal JM Ellenberger T (2006) DNA ligases: structure, reaction mechanism and function. Chem Rev 106: 687-699

van Wolferen M, Ajon M, Driessen AJM, Albers SV (2013) How hyperthermophiles adapt to change their lives: DNA exchange in extreme conditions. Extremophiles 17: $545-563$

Wang Y, Xie J, Han Z, Liu J, Liu X (2013) Expression, purification and biochemical characterization of Methanocaldococcus jannaschii DNA ligase. Protein Expr Purif 87: $79-86$

Wilkinson A, Day J, Bowater R (2001) Bacterial DNA ligases. Mol Microbiol 40: $1241-1248$

Zakabunin AI, Kamynina TP, Khodyreva SN, Pyshnaya IA, Pyshnyi DV, Khrapov EA, Filipenko ML (2011) Gene cloning, purification, and characterization of recombinant DNA ligases of the thermophilic archaea Pyrococcus abyssi and Methanobacterium thermoautotrophicum. Mol Biol 45: 229-236 
Zhang L, Huang Y, Xu D, Yang L, Qian K, Chang G, Gong Y, Zhou X, Ma K (2016) Biochemical characterization of a thermostable $\mathrm{HNH}$ endonuclease from deep-sea thermophilic bacteriophage GVE2. App1 Microbiol Biotechnol 100: 8003-8012

Zhao A, Gray FC, MacNeill SA (2006) ATP- and NAD+-dependent DNA ligases share an essential function in the halophilic archaeon Haloferax volcanii. Mol Microbiol 59: $743-752$

\section{Figure legends}

Fig. 1 T. barophilus Tba Ch5 encodes a DNA ligase that can join the nicked DNA. A. Partial amino acid alignment in the conserved of DNA ligases from crenarchaea, euryarchaea, eukaryotes and virus. Tba: Thermococcus barophilus (NCBI reference sequence: WP_013468226.1); Tsp: Thermococcus sp. 1519 (PDB: 3RR5); Tsi: Thermococcus sibiricus (PDB: 4EQ5); Pfu: Pyrococcus furiosus (PDB (Protein Data Bank: 2CFM); Afu: Archaeoglobus fulgidus (PDB: 3GDE); Sso: (PDB: 2HIX); Hu1: human ligase I (NP_000225); Sce: Saccharomyces cerevisiae (P04819); T7: bacteriophage T7 DNA ligase (P00969). The conserved amino acid residues are bolded. B. Expression and purification of Tba ligase. Tba ligase was over expressed with IPTG and purified by sonication, heat treatment $\left(70^{\circ} \mathrm{C}\right.$ for $\left.20 \mathrm{~min}\right)$ and $\mathrm{Ni}$ column affinity purification. $\mathbf{C}$ and D. Tba ligase joined the nicked DNA. DNA ligation assays of the enzyme were performed by adding various enzyme concentrations to the reaction mixtures containing nicked plasmid (C) or nicked nucleotide duplex (D) as substrates. CK: reaction without the enzyme.

Fig. 2 Tba ligase is a thermostable enzyme. A. The optimal reaction temperature of the enzyme activity. DNA ligation reactions of Tba ligase were performed at various temperatures for $10 \mathrm{~min}$. B. To evaluate its thermo-tolerance, Tba ligase was heated at 90,95 and $100^{\circ} \mathrm{C}$ for $30 \mathrm{~min}$. DNA ligation reactions of the heated Tba ligase were monitored for 2, 5 and $10 \mathrm{~min}$. C. Tba ligase was heated at $100^{\circ} \mathrm{C}$ for $1,2,3$ and 4 hours. The heated enzyme was used to perform DNA ligation for 5 and $15 \mathrm{~min}$. CK: reaction without the enzyme.

Fig. 3 Effects of various divalent metal ions on Tba ligase activity. Various divalent 
metal ions with various concentrations $(0.1,0.5$ and $2 \mathrm{mM})$ were added to the DNA ligation reactions catalyzed by the Tba ligase using 200 ng nicked pET-30a (+) DNA as substrate. A. $\mathrm{Ca}^{2+}, \mathrm{Mg}^{2+}, \mathrm{Fe}^{2+}$ or $\mathrm{Mn}^{2+} ;$ B. $\mathrm{Zn}^{2+}, \mathrm{Cu}^{2+}, \mathrm{Ni}^{2+}$ or $\mathrm{Co}^{2+}$. C. DNA ligation reactions were performed by the Tba ligase with $2.0 \mathrm{mM}$ above divalent metal ions, using a nicked nucleotide duplex as substrate. CK1: reaction without the enzyme. CK2: reaction without ion in the presence of the enzyme.

Fig. 4 Effects of $\mathrm{pH}$ and salinity on Tba ligase activity. A and B. Optimal pH of Tba ligase activity. Using the nicked nucleotide duplex (A) and nicked plasmid (B) as substrates, DNA ligation reactions were carried out by Tba ligase using buffers at various $\mathrm{pHs}(\mathrm{pH} 4-10)$. C and D. Impact of salinity on Tba ligase activity. Using the nicked nucleotide duplex (C) and nicked plasmid (D) as substrates, DNA ligation reactions were carried out at various $\mathrm{NaCl}$ concentrations. $\mathrm{CK}$ : reaction without the enzyme.

Fig. 5 Effect of various nucleotide cofactors on Tba ligase activity. A. Using nicked pET-30a $(+)$ as substrate, DNA ligation reactions were carried out with $1.0 \mathrm{mM}$ NTPs, dNTPs or NAD ${ }^{+}$. B. DNA ligation reactions were carried out with $1.0 \mathrm{mM}$ NTPs, dNTPs or NAD ${ }^{+}$using the nicked nucleotide duplex as the substrate. CK1: reaction without the enzyme. CK2: reaction with enzyme in absence of any nucleotide cofactor.

Fig. 6 NanoLC-MS/MS spectrum for the identification of AMPlyation of Tba ligase.

Fig. 7 Kinetics of DNA ligation by Tba ligase. A. DNA ligation reactions were performed in presence of nicked plasmid in the optimal reaction buffer for various reaction times (5-120 min). B. DNA ligation reactions were performed in presence of nicked nucleotide in the optimal reaction buffer for various reaction times $(0.5-20$ $\min )$. CK: reaction without the enzyme.

Fig. 8 Effect of mismatches on DNA ligation activity of Tba ligase. A. The Cy3labeled nucleotide DNA (*p22), the phosphorylated nucleotides (p37), and the complementary nucleotides (p59) were annealed to prepare the nicked DNA substrates with various match and mismatches at the first position $5^{\prime}$ or $3^{\prime}$ adjacent to 
the nick. B. DNA ligation reactions were performed under the optimal conditions. CK: reaction without the enzyme.

Fig. 9 LCR by Tba ligase. The Cy3-labeled nucleotide DNA (*p22), the phosphorylated nucleotides (p37), and the complementary nucleotides (t59) were used as substrates to perform LCR reactions. CK: reaction without the enzyme. 
Table 1 Oligonucleotides used in this study.

\begin{tabular}{ll}
\hline Name & Sequence $\left(5^{\prime}-3^{\prime}\right)$ \\
\hline Tba Lig F & GGG AATTCCATA TGCTGTACAAAGAGTTGGCCG \\
\hline Tba Lig R & CCGCTCGAGTTTAGTAATATTTAAGCTTTTCC-3' \\
\hline K250A F & GAAGCAGAGTTCGAAATTGCATACGACGGTGCAAGA \\
\hline K250A R & TGCAATTTCGAACTCTGCTTCGCCCCCCATTTCGAC \\
\hline p22 & CAGTGA ATTCGAGCTCGGTACC \\
\hline p37 & ${ }^{\text {*CGGGGATCCTCTAGAGTCGACCTGCAGGCATGCAAGC }}$ \\
\hline t59 & GCTTGCATGCCTGCAGGTCGACTCTAGAGGATCCCCN ${ }_{2}{ }_{2} G T$ \\
& ACCGAGCTCGAATTCACTG \\
\hline
\end{tabular}

The underlined nucleotides represent restriction sites.

The mutagenic nucleotides are italic.

*: phosphorylated; $\mathrm{N}_{1}$ : A, T, C and G; $\mathrm{N}_{2}$ : A, T, C and G. 